Spo2 cho từng bệnh nhân để đánh giá rối loạn nuốt và trình độ của điều dưỡng viên hiện nay còn khá là hạn chế trong việc nghe và đánh giá tim, phổi của người bệnh cho nên các bước này chỉ có số ít điều dưỡng viên thực hiện.

Việc đưa ra quyết định người bệnh có bị rối loạn nuốt hay không và phương pháp dinh dưỡng cho người bệnh là rất quan trọng để tránh những biến chứng nguy hiểm xảy ra. Kết quả nghiên cứu cho thấy toàn bộ điều dưỡng viên tham gia nghiên cứu xác định được test nuốt thất bại hoặc test nuốt thành công và điều dưỡng viên đưa ra được phương pháp cho ăn phù hợp với mức độ rối loạn nuốt theo quy định.

Việc đánh giá, phát hiện sớm các biểu hiện lâm sàng rối loạn nuốt ở người bệnh đột quy nã̃o không những giúp hạn chế nguy cơ viêm phổi hít mà còn giúp giảm nguy cơ suy dinh dưỡng, giảm thời gian nằm viện và tỉ lệ tử vong. Vì vậy điều dưỡng viên cần phải nắm rõ kiến thức, thực hiện đầy đủ các quy trình để phát hiện sớm rối loạn nuốt của người bệnh từ đó đưa ra được kế hoạch chăm sóc phù hợp đảm bảo dinh dưỡng, an toàn và tránh được các biến chứng nguy hiểm có thể xảy ra.

\section{KẾT LUẬN}

Tình trạng rối loạn nuốt xảy ra ở hầu hết người bệnh đột quỵ. não vì vậy việc sử dụng thang điểm Guss của ĐDV trong chăm sóc rổi loạn nuốt ở người bệnh đột quy não rất quan trọng. Kết quả nghiên cứu cho thấy tỉ lệ ĐDV xác định được kết quả test nuốt chiếm tî lệ cao (100\%). Tuy nhiên khi sử dụng thang điểm Guss có một số bước ĐDV thực hiện thấp như: đánh giá giọng người bệnh lần lượt là $24,7 \%, 28,4 \%$,
25,9\%; đánh giá Sp02 2,5\%, ĐDV nghe phổi hoặc phối hợp với bác sĩ đánh giá tiếng phổi của người bệnh cao nhất là $6,2 \%$. Việc đánh giá, phát hiện sớm các biểu hiện lâm sàng rối loạn nuốt ở người bệnh đột quyy. não không những giúp hạn chế nguy cơ viêm phổi hít mà còn giúp giảm nguy cơ suy dinh dưỡng, giảm thời gian nằm viện và tỉ lệ tử vong. Vì vậy điều dưỡng viên cần phải nắm rõ̉ kiến thức, thực hiện đầy đủ các quy trình để phát hiện sớm rối loạn nuốt của người bệnh từ đó đưa ra được kế hoạch chăm sóc phù hợp đảm bảo dinh dưỡng, an toàn và tránh được các biến chứng nguy hiểm có thể xảy ra.

\section{TÀI LIẸU THAM KHẢO}

1. Tăng Thi Hảo, Tăng Thị Hải, Đỗ Minh Sinh (2019). Một số yếu tố liên quan đến stress nghể nghiệp ở ĐDV tại Bệnh viện Nhi Thái Bình. Khoa học Đ̇iêu dưỡng, 03(05), 46-54.

2. Ngô Huy Hoàng (2018). Thay đổi nhân thức của ĐDV lâm sàng về chăm sóc tư thế và̀ vận động sớm cho người bệnh đột quy tại bệnh viện Đa khoa tỉnh Nam Định. Tạp chí khoa học điêuu dưỡng, $01(01), 20-27$.

3. Trân Đại Hoàng, Pham Quang Hòa (2017). Thực trạng và một số yểu tổ ảnh hưởng đến nhân lực điều dưỡng tại 6 bệnh viện tỉnh Thái Bình năm. K̉hoa học Điêu Dưỡng, 01(02), 78-83.

4. Nguyến Thị Khuyến (2018). Thực trạng kiến thức về rối loạn nuốt cúa điều dươning tại 2 bệnh viện Đa khoa trung tâm tỉnh Vính Phúc năm 2018. Trường Đại học Điêuu dưỡng Nam Định.

5. Vũ Thị Minh Phượng, Trấn Thị Thanh Mai, Mai Thị Yến (2017). Nhu câu tìm kiếm thông tin về đốt quy não của người nhà bệnh nhân tại khoa thần kinh bênh viên đa khoa tỉnh Nam Định năm 2017. Tapp chí khoa học Điêu dưỡng, 03(02), 114-119.

6. Nguyễn Đức Trung, Nguyễn Văn Liệu (2016). Nghiên cứu rối loann nuốt ở bệnh nhân nhồi máu não bằng thang điểm của Mann và đánh giá các yếu tố liên quan. Tạp chí Y Dược học quân sự, 64-68.

\title{
ĐẶC ĐIỂM LÂM SÀNG, XQUANG TRÊN PHIM CEPHALOMETRICS BỆNH NHÂN SAI KHỚP CẤN LOẠI II ĐIỀU TRI VỚI KHÍ CỤ CHỨC NĂNG TWICARE
}

\section{TÓM TẮT.}

Mục tiêu: xác định các đặc điểm lâm sàng và các số đo đặc trưng trên phim sọ nghiêng Cephalometrics

*Bệnh viện Răng Hàm Mặt Trung Ương Hà Nội,

Chịu trách nhiệm chính: Võ Thị Thuý Hồng

Email: vothuyhong71@yahoo.com

Ngày nhận bài: 13.9.2021

Ngày phản biện khoa học: 15.11.2021

Ngày duyệt bài: 22.11.2021
Võ Thị Thuý Hồng*

ở các bệnh nhân sai khớp cắn loại II đang tăng trưởng điều trị với khí cụ chức năng Twicare. Phương pháp nghiên cứu: nghiên cứu mô tả cắt ngang. Kết quả: đắc điểm lâm sàng góc mũi môi nhọn $41,2 \%$, khớp cắn sâu $70,59 \%$, khớp cắn răng hàm loại II 2 bên $82,4 \%$. Độ cắn chìa, cắn trùm tăng $(7,32 \pm 2,14$ và $4,32 \pm 1,89)$. Xương hàm trên bình thường với góc SNA là $83,06 \pm 2,84$ và xương hàm dưới lùi với góc SNB là $76,29 \pm 2,64$. Kết luận: Đặc điểm lâm sàng và XQuang cho thây các bệnh nhân sai khớp cắn loại II điêu trị với khí cụ chức năng Twicare có độ cắn chìa và cắn 
trùm tăng, lùi xương hàm dưới và hàm trên bình thường. Tứ khoá: Lùi xương hàm dưới, sai khớp cắn loại II, khí cụ chức năng Twicare, đang tăng trưởng.

\section{SUMMARY \\ CLINICAL AND CEPHALOMETRIC X RAY CHARACTERISTICS OF CLASS II PATIENTS TREATING WITH TWICARE FUNCTIONAL APPLIANCE}

Objective: to analyze clinical features and Cephalometrics analysis of class II malocclusion in growing patients treated by Twicare appliance. Method: a cross-sectional descriptive study. Results: nasolabial angle lower than normal analysis $41.2 \%$; deepbite $70.59 \%$; both sides class II dental $82,4 \%$; large overjet and overbite (7.32 2.14 và $4.32 \pm 1.89)$; normal maxillary (SNA $=83.06 \pm 2.84^{\circ}$ ) and mandibular retrognathia $\left(\mathrm{SNB}=76.29 \pm 2.64^{\circ}\right.$ ). Conclusion: Clinical and radiographic characteristics showed that patients with class II malocclusion treated by Twicare functional appliance have large overjet and overbite, and normal maxillary and mandibular retrusion. Key words: Mandibular retrusion, class II malocclusion, Twicare functional appliance, growing patient.

\section{I. ĐĂT VẤN ĐỀ}

Sai khớp cắn ở trẻ em chiếm tỉ lệ cao trong số các bệnh nhân đến khám tại các cơ sở khám chữa bệnh chuyên ngành Nắn chỉnh răng. Nguyên nhân sai khớp cắn ở trẻ em rất đa dạng và thói quen xấu là một trong các nguyên nhân. Thói quen xấu gây ra sai lệch khớp cắn do có sứ mất cân bằng giữa hệ thống cơ ở vùng miệng và hàm mặt. Sai khớp cắn loại II thường gặp khi trẻ có các thói quen xấu như mút môi dưới, bú bình, thở miênng, đầy lưỡi... với đặc trưng như xương hàm trên hẹp và xương hàm dưới kém phát triển. Trong sai khớp cắn loại II nhiều nghiên cứu đã chỉ ra rằng phần lớn các trường hợp do xương hàm dưới kém phát triển ${ }^{1,2}$.

Việc điều trị ở lứa tuổi răng hỗn hợp mang lại hiệu quả cao do đây là thời kỳ trẻ còn đang tăng trưởng, xương hàm còn đang phát triển, các cơ và mô mềm cũng đang trong thời kỳ tăng trưởng do đó dễ dàng chỉnh sửa các sai lệch do quá trình phát triển gây nên ${ }^{3}$. Khi phát hiện có các sai lệch ở bộ răng hỗn hợp cân hỏi bệnh và thăm khám kỹ để phát hiện ra các nguyên nhân và loại bỏ chúng thì kết quả điêu trị mới ổn định và tránh được tái phát. Để dễ dàng chẩn đoán và chỉ định khí cụ điều trị các đặc điểm lâm sàng và XQuang trên phim Cephalometrics của các loại hình sai khớp cắn cần được phát hiện và ghi nhận. Do đó chúng tôi đã tiến hành nghiên cứu: "Đặc điểm lâm sàng, XQuang trên phim Cephalometrics bệnh nhân sai khớp cắn loại II điều trị với khí cụ chức năng Twicare", nhằm xác định các đặc điểm lâm sàng và các số đo đặc trưng trên phim sọ nghiêng Cephalometrics ở các bệnh nhân trên.

\section{II. ĐỐI TƯỢNG VÀ PHƯƠNG PHÁP NGHIÊN CỨU \\ Thời gian \& địa điểm nghiên cứu: từ} tháng 7 năm 2016 đến tháng 6 năm 2018 tại Khoa nắn chỉnh răng, Bệnh viện răng hàm mặt trung ương Hà Nội.

Đối tượng nghiên cứu: Là các bệnh nhân sai khớp cắn loại II còn trong độ tuổi tăng trưởng, được chỉ định điều trị với khí cụ chức năng Twicare.

Tiêu chuẩn chọn lựa: Bệnh nhân 7-15 tuổi đến khám nắn chỉnh rắng được chẩn đoán sai khớp cắn loại II xương do nguyên nhân lùi hàm dưới được điều trị với khí cụ chức năng Twicare. Khám lâm sàng: Kiểu mặt lồi, hàm dưới lùi, khi đưa hàm dưới ra trước mặt nghiêng thay đổi, giảm mức độ lồi của mặt và trở nên đẹp hơn sát gần với tiêu chuẩn mặt thẳng. Đo trên phim Cephalometric: xương loại II với góc ANB > 4 độ và chỉ số Wits $>2,1 \mathrm{~mm}$. Loại trừ bệnh nhân có dị tật bẩm sinh vùng hàm mặt: khe hở môi vòm miệng, khe hở ngang mặt... hoặc có tiền sử chấn thương vùng hàm mặt có ảnh hưởng đến khớp cắn; có phản ứng dị ứng với các thành phần của hàm twicare; không hợp tác.

Phương pháp nghiên cứu: nghiên cứu mô tả cắt ngañ.

Cõ̃ mâ̂u: chon cõ̃ mẫu nhỏ nhất có ý nghĩa trong nghiên cứu mô tả trên lâm sàng, thực tế nghiên cứu trên 34 bệnh nhân.

Phương tiện nghiên cứu: bệnh án nghiên cứu, phim sọ nghiêng Cephalometrics, phần mềm vẽ phim V-Ceph. Các chỉ số đo đạc trên phim trong nghiên cứu được so sánh với giá trị bình thường của người Châu âu, Châu á.

Biến số nghiên cứu: Biến số khám lâm sàng như tuổi, giới, thói quen xấu, góc mũi môi, khớp cắn theo phân loại Angle, độ cắn chìa, độ cắn trùm. Các chỉ số đo trên phim sọ nghiêng Cephalometrics: SNA, SNB, ANB, Wits, U1-SN, U1-ANSPNS, 1L-Md, 1U-1L, góc mũi môi, Li-E, Ls-E.

Xử lý số liệu: với phần mềm thống kê SPSS 16.0.

Đạo đức nghiên cứu: Nghiên cứu được chấp thuận bởi Hội đồng đề tài cấp cơ sở Bệnh viện răng hàm mặt trung ương Hà nội. Thổng tin thu thập được giữ bí mật và chỉ phục vụ mục đích nghiên cứu và đề xuất can thiểp, không nhằm mục đích nào khác. Bệnh nhân được thông báo và đồng ý chấp nhận tham gia nghiên cứu. 

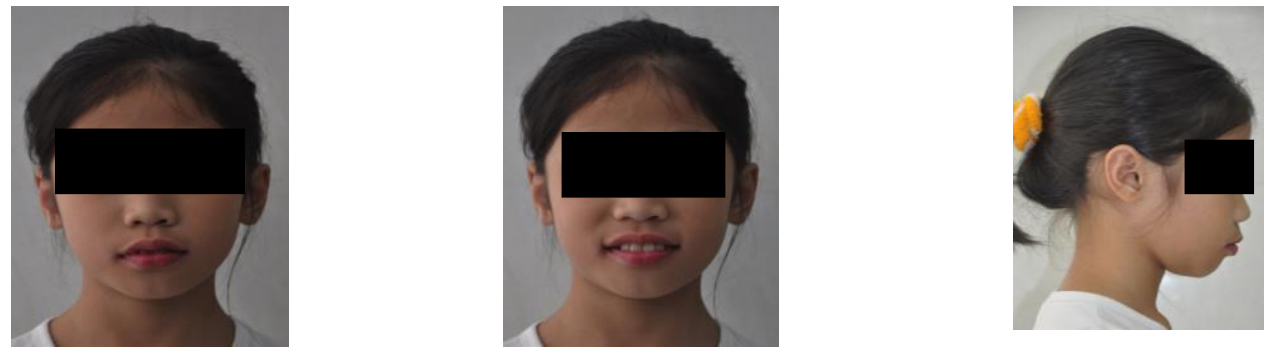

Hình 2.1. Hình ảnh mặt ngoài bệnh nhân trước điều trị

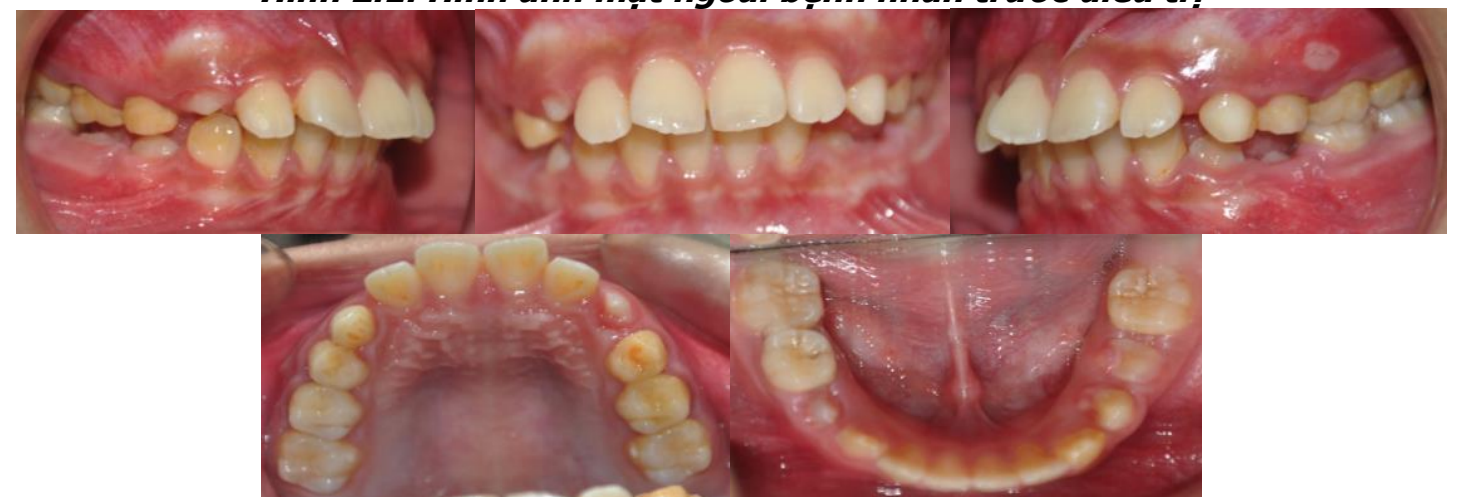

Hình 2.2. Hình ảnh trong miệng bệnh nhân trước điều trị

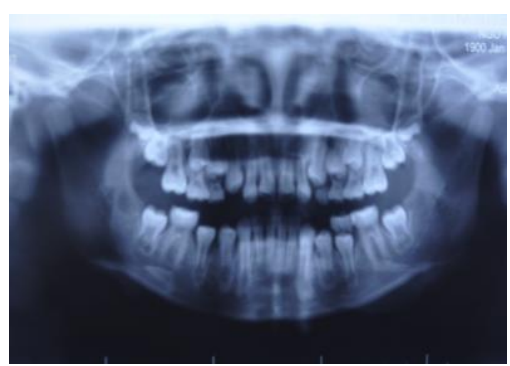

Hinh 2.4. Hình ảnh phim panorama bệnh nhân trước điều trị

III. KẾT QUẢ NGHIÊN CỨU

\subsection{Phân bố theo giới}

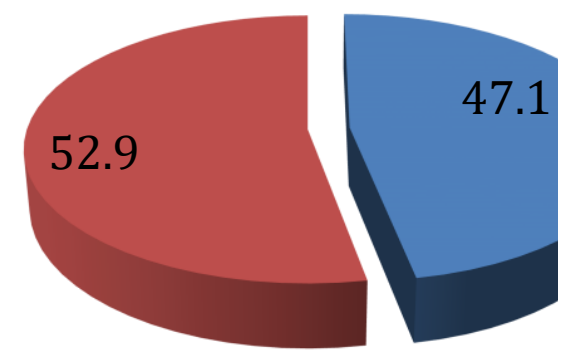

Biểu đồ 3.1. Phân bô theo giới

Nhận xét: Trong số 34 bệnh nhân, có 16 nam (chiếm 47,1\%), 18 nữ (chiếm 52,9\%). Sữ khác biệt giữa nam và nữ không có ý nghĩa thống kề với $p>0,05 .(p=0,732)$.

3.2. Phân bố theo tuối

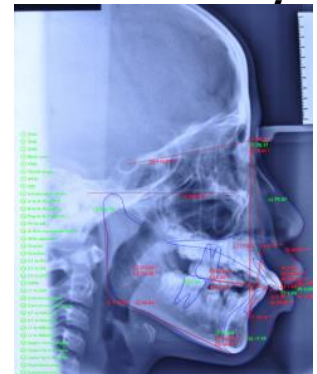

Hình 2.4. Hình ảnh phân tích phim mặt nghiêng bệnh nhân trước điều trị

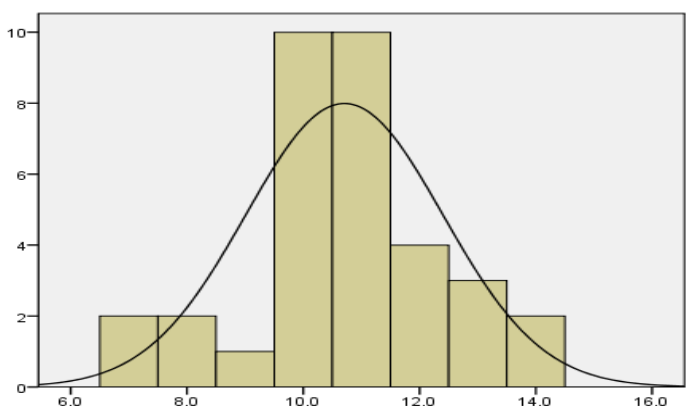

Biểu đồ 3.2. Phân bố theo tuổi

Nhận xét: Độ tuổi trung bình bắt đầu điều trị của mẫu nghiển cứu là $10,7 \pm 1,7$ năm. Bệnh nhân nhỏ tuổi nhất là 7 tuổi, lớn nhất là 14 tuổi. Độ tuổi trung bình của nhóm nam là $11,3 \pm 1,9$ tuổi, nhóm nữ trung bình $10,2 \pm 1,34$ tuổi, sự khác biệt có ý nghĩa thống kê với $p=0,049$.

3.3. Đặc điểm lâm sàng 
Bảng 3.1: Đặc điểm khám lâm sàng

\begin{tabular}{|c|c|}
\hline Đắc điếm khám lâm sàng & $\mathbf{n ~ ( \% )}$ \\
\hline $\begin{array}{c}\text { Khớp cắn răng hàm loại I bên } \mathrm{P}, \\
\text { loại II bên T }\end{array}$ & $1(2,9)$ \\
\hline Khớp cắn răng hàm loại I 2 bên & $5(14,7)$ \\
\hline Khớp cắn răng hàm loại II 2 bên & $28(82,4)$ \\
\hline Khớp cắn sâu & $24(70,59)$ \\
\hline Thói quen xấu & $5(14,7)$ \\
\hline Góc mũi môi nhọn & $14(41,2 \%)$ \\
\hline
\end{tabular}

Nhân xét: 34 bênh nhân không phải đều là khớp cắn loai II theo phân loại Angle mà có 5 bệnh nhân có khớp cắn răng hàm loại I và 1 bệnh nhân có răng hàm một bên loại I một bên loại III.

Bảng 3.2: Mức độ cắn chìa và cắn trùm trước điều trị

\begin{tabular}{|c|c|c|c|c|}
\hline $\begin{array}{l}\text { Đăc điểm } \\
\text { khớp cắn } \\
\text { trước ĐT }\end{array}$ & $\begin{array}{c}n \\
(0- \\
3 \mathbf{m m})\end{array}$ & $\begin{array}{c}\mathbf{n} \\
(4- \\
7 \mathbf{m m})\end{array}$ & $\begin{array}{c}n \\
(>7 m m \\
)\end{array}$ & $\begin{array}{c}\text { Tổng số } \\
\text { n }(X \pm D \\
\text { mm) }\end{array}$ \\
\hline $\begin{array}{l}\text { Độ cắn } \\
\text { chìa }\end{array}$ & 1 & 19 & 14 & $\begin{array}{c}34 \\
(7,32 \pm 2,14\end{array}$ \\
\hline $\begin{array}{c}\text { Độ cắn } \\
\text { trùm }\end{array}$ & 10 & 22 & 2 & $\begin{array}{c}34 \\
(4,32 \pm 1,89\end{array}$ \\
\hline
\end{tabular}

Nhận xét: Các bênh nhân nghiên cứu phần lớn có độ cắn chìa tắng nhưng chỉ có 24 bệnh nhân có độ cắn trùm tăng.

3.4. Đặc điểm $X Q u a n g$ trước điều trị

Bảng 3.3: Đặc điểm XQuang trên phim Cephalometrics

\begin{tabular}{|c|c|c|}
\hline Chỉ số & Bình thường & $\mathbf{n}(\mathbf{X} \pm \mathbf{D})$ \\
\hline SNA & $82^{\circ} \pm 2$ & $83,06 \pm 2,84$ \\
\hline SNB & $80^{\circ} \pm 2$ & $76,29 \pm 2,64$ \\
\hline ANB & $2^{\circ} \pm 2$ & $6,68 \pm 2,01$ \\
\hline Wits & $0-2$ & $4,81 \pm 2,31$ \\
\hline U1-SN & $103^{\circ} \pm 1$ & $112,88 \pm 9,77$ \\
\hline U1-ANSPNS & $110^{\circ} \pm 5$ & $122,21 \pm 9,27$ \\
\hline 1L-Md & $95^{\circ} \pm 5$ & $96,76 \pm 7,32$ \\
\hline 1 U-1L & $125^{\circ}-130$ & $114 \pm 13,96$ \\
\hline Góc mũi môi & $102^{\circ} \pm 2$ & $93,88 \pm 13,45$ \\
\hline Li-E & $-2 \pm 2 \mathrm{~mm}$ & $4,56 \pm 1,6$ \\
\hline Ls-E & -1 đến $-4 m m$ & $3,91 \pm 2,45$ \\
\hline
\end{tabular}

Nhận xét: Góc SNA trong giới hạn bình thường, góc SNB giảm so với giá trị bình thường, góc ANB tăng, chỉ số Wits tăng. Góc mũi môi giảm và góc liên răng cửa $1 \mathrm{U}-1 \mathrm{~L}$ giảm. Các chỉ số về răng U1-ANSPNS, $1 \mathrm{~L}-\mathrm{Md}$ tăng. Môi trên và môi dưới so với đường thẩm mỹ $E$ (chỉ số Li-E và Ls-E) tăng.

\section{BÀN LUÂ̂N}

Đặc điểm lâm sàng và XQuang các bênh nhân sai khớp cắn loại II điều trị với khí cụ Twicare.

- Biểu đồ 3.1, trong 34 bệnh nhân nghiên cứu có 16 nam (chiếm 47,1\%), 18 nữ (chiếm 52,9\%). Như vậy, tỉ lệ trẻ nam xấp xỉ so với nữ, điều này cho thấy hàm răng đều đẹp là vấn đề quan tâm của bố mẹ, không phân biệt con trai hay gái.

- Biểu đồ 3.2, tuổi trung bình điều trị trong nghiên cứu là $10,7 \pm 1,7$. So với các nghiên khác sử dụng khí cụ chức năng điều trị sai khớp cắn loại II như nghiên cứu của Antatas ${ }^{4}$ tuổi trung bình là 10,2 , còn nghiên cứu của Aisha ${ }^{5}$ tuổi trung bình của nam là $11,4 \pm 1,71$ và nữ là 11,8 $\pm 1,62$, nghiên cứu của chúng tôi có tuổi trung bình điều trị tương tự. Tuổi đeo khí cụ chức năng có hiệu quả nhất là ở giai đoạn CS3 nghĩa là trong khoảng thời gian khoảng 2-3 năm quanh đỉnh điểm của thời kỳ dậy thì.

-Tuổi sớm nhất trong nghiên cứu là 7 tuổi và tuổi nhiều nhất là 14 tuổi. Ở tuổi 13 và 14 là giai đoạn rất sát hoặc vừa qua đỉnh điểm của thời kỳ tăng trưởng vì vậy ở giai đoạn này cần có khí cụ lắp ngay cho bệnh nhân để tận dụng đỉnh tăng trưởng khi đẩy hàm ra trước. Khí cụ Twicare là khí cụ chức năng đồng thời là khí cụ điêuu trị loại bỏ thói quen xấu do cấu tạo gồm hai máng cao su mềm ngăn cản các lực tác động lên răng và vì thế làm đều các răng khấp khểnh nhẹ. Với ưu điểm máng cao su mềm nên khí cụ Twicare có kết hợp sử dụng cùng gắn mắc cài để sắp xếp và làm thẳng hàng các răng. Do đó khí cụ sử dụng được với cả các bệnh nhân đến ở giai đoạn sớm cũng như các bệnh nhân đến ở giai đoạn muộn đã dậy thì được 1-2 năm. Với lợi thế như vậy khí cụ Twicare tỏ rõ lợi thế so với khí cụ chức năng gẳn chă̆t Forsus được sử dụng phổ biến tại Việt nam. Thông thường khí cụ Forus sẽ lắp cho bệnh nhân sau khoảng 6-9 tháng sắp thẳng hàng các răng tính từ thời điểm gắn mắc cài. Do đó các bệnh nhân đến ở giai đoạn muộn sẽ cần thời gian để làm đều và làm phẳng đường cong spee trước khi lắp khí cụ và như vậy sẽ có thể bỏ lõ thời điểm kích thích đưa xương hàm dưới ra trước có hiệu quả nhất.

- Các bểnh nhân điều trị với khí cụ Twicare có các đặc điểm lâm sàng điển hình của bệnh nhân sai khớp cắn loại II, do khi chọn lựa bệnh nhân nghiên cứu chúng tôi đã chọn các bệnh nhân có kiểu mặt lồi và đo trên phim Cephalometric góc ANB $>4$ độ và Wits $>2,1 \mathrm{~mm}$. 34 bệnh nhân nghiên cứu, $100 \%$ bệnh nhân có kiểu mặt lồi do chọn chủ đích, nhưng bệnh nhân có góc mũi môi nhọn chỉ có 14 bệnh nhân chiếm tỉ lệ $41,2 \%$ (bảng 3.1). Góc mũi môi nhọn thường do vẩu răng hoặc do vẩu xương hàm trên.

- Nghiên cứu có 5 bệnh nhân có thói quen xấu chiếm 14,7\% (bảng 3.1), các thói quen xấu 
này là một trong các nguyên nhân gây ra sai khớp cắn loại II xương và lùi hàm dưới. Khí cụ Twicare có cấu trúc là máng cao su mềm, khi đeo sẽ ngăn cản tác động của mô mềm như môi má, lưỡi đồng thời đưa hàm dưới ra trước do đó khi đeo sẽ ngăn ngừa được các thói quen xấu cho bệnh nhân.

- 34 bệnh nhân trong nghiên cứu có 5 bênh nhân có khớp cắn loại I cả hai bên chiếm tỉ lệ $14,7 \%$, có 1 bệnh nhân có khớp cắn loại I một bên (bảng 3.1). Khớp cắn loại I ở bệnh nhần xương loại II có thể do sự bù trừ rất tốt của cơ thể để đảm bảo chức năng nhai hoặc có thể do mất răng sữa sớm nên đã khiến răng 6 dưới di chuyển ra trước và tạo thành khớp cắn loại $\mathrm{I}$. Tuy nhiên phần lớn các trường hợp trong nghiên cứu đều có khớp cắn loại II theo phân loại Angle (82,4\%).

- Độ cắn chìa trung bình trong nghiên cứu là $7,32 \pm 2,14$ cho thãy mức độ nặng của sai khớp cắn (bảng 3.2). Số bệnh nhân có độ cắn chìa trên $7 \mathrm{~mm}$ là 14 bệnh nhân cho thẩy mức độ nặng của sai khớp cắn loại II xương và sự chênh lệch giữa xương hàm trền và xương hàm dưới tăng. Có 1 bệnh nhân có độ cắn chìa bình thường, đây là bệnh nhân sai khớp cắn loại II tiểu loại II và trục răng cửa hàm trên ngả môi, chúng tôi điều trị gắn mắc cài để đưa trục răng cửa trên ra trước và sử dụng khí cụ Twicare để chỉnh đưa xương hàm dưới ra trước.

- Độ cắn phủ trung bình trong nghiên cứu là 4,32 $\pm 1,89$, 24 trong 34 bệnh nhân nghiên cứu có cắn sâu. Số liệu này cho thấy các bệnh nhân sai khớp cắn loại II xương có lùi hàm dưới thường phối hợp với cắn sâu.

- Các chỉ số đo trên phim Xquang cho thây góc SNA $83,06 \pm 2,84$, giá trị này nằm trong giá trị bình thường so với người da trắng hoặc Nhật bản, cho thây xương hàm trên của các bệnh nhân nghiên cứu là bình thường (bảng 3.3). Góc SNB trong nghiên cứu có giá trị trung bình là $76,29 \pm 2,64$ so giá trị trung bình theo tiêu chuẩn của người Châu Âu da trắng và người Nhật bản thì góc SNB giảm. Chỉ số SNB giảm cho thấy các bệnh nhân có lùi xương hàm dưới. Nghiên cứu của chúng tôi có xương hàm trên nằm trong giá trị bình thường, xương hàm dưới lùi. Xương hàm dưới lùi đã dẫn tới góc ANB tăng cao và chỉ số Wits tăng cao. Nghiên cứu của chúng tôi có cùng nhận định với các nghiên cứu khác như nghiên cứu của Moyers năm $1980^{6}$, thấy xương hàm trên bình thường kết hợp với lùi xương hàm dưới trong sai khớp cắn loại II chiếm tỉ lệ tới $70 \%$. Nghiên cứu của McNamara năm 1981², 277 trẻ có sai khớp cắn loại II thì $60 \%$ là lùi xương hàm dưới.

- Góc ANB trung bình trong nghiên cứu là $6,68 \pm 2,01$ và chỉ số Wits trung bình là $4,81 \pm 2,31$ cho thấy mức độ mất cân xứng giữa xương hàm trên và xương hàm dưới nhiều (bảng 3.3).

- Các chỉ số về răng như trục răng cửa hàm trên so với mặt phẳng nền sọ SN và mặt phẳng xương hàm trền ANS-PNS tăng cao so với giá trị bình thường (U1-SN là $112,88 \pm 9,77$ và U1ANSPNS là $122,21 \pm 9,27$ ) cho thây các bệnh nhân có răng cửa hàm trên ngả ra trước. Các răng cửa hàm trên ngả ra trước đã dẫn tới góc mũi môi nhọn.

- Góc liên răng cửa $1 U$-1L là $114 \pm 13,96$ cho thấy góc liên răng cửa nhọn so với giá trị bình thường. Trục răng cửa hàm dưới (góc $1 \mathrm{~L}-\mathrm{Md}$ là $114 \pm 13,96$ độ) so với mặt phẳng hàm dưới tăng cao so với giá trị bình thường, nguyên nhân do răng cửa hàm dưới ngả ra trước nhiêu để bù trừ sự mất cân xứng xương (bảng 3.3).

- Về mô mềm góc mũi môi trung bình là $93,88 \pm 13,45$ độ cho thây phần lớn các bệnh nhân có vẩu răng và xương ổ răng hàm trên do giả trị góc SNA nằm trong giá trị bình thường. Giá trị Li-E và Li-E đều tăng cao cho thấy thẩm mỹ của khuôn mặt của bệnh nhân bị ảnh hưởng do sự lùi xương hàm dưới và do cằm bệnh nhân kém phát triển, đồng thời sự ngả ra trước của răng cửa hàm dưới đã đẩy cho môi dưới nhô ra trước (bảng 3.3).

\section{KẾT LUẬN}

Đặc điểm lâm sàng, Xquang các bệnh nhân sai khớp cắn loại II điều trị với khí cụ Twicare:

- Tỉ lệ nam và nữ không có sự khác biệt có ý nghĩa thống kê. Tuổi trung bình bắt đầu điều trị là $10,7 \pm 1,7$. Các bệnh nhân có các đặc điểm đặc trưng của sai khớp cắn loại II xương do lùi hàm dưới với kiểu mặt lồi, góc mũi môi nhọn là $41,2 \%$, khớp cắn sâu $70,59 \%$, khớp cắn răng hàm loại II 2 bên là $82,4 \%$.

- Độ cắn chìa, cắn trùm tăng $(7,32 \pm 2,14 \mathrm{~mm}$ và $4,32 \pm 1,89 \mathrm{~mm}$ ). Xương hàm trên bình thường với góc SNA là $83,06 \pm 2,84$ độ và xương hàm

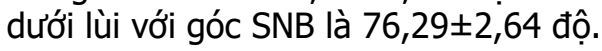

\section{TÀI LIẸU THAM KHẢO}

1. Ngọc V.T.N, Hanh T.T.M, Nga Đ.T.H (2014), Răng trẻ em tập 2. Nhà xuất bản Y Học, 164-166.

2. McNamara j.A., Jr. (1981), Components of class II malocclusion in children 8-10 years of age. Angle Orthod. 51(3), 177-202.

3. Medventiv (2015), Prospective multicentric, open-label, randomized Study assessing the efficacy of the removable and adjustable preformed Twicare ${ }^{\circledR}$ appliance versus removable 
Herbst treatment in class II malocclusion.

4. Sidlauskas A. (2005), The effects of the Twinblock appliance treatment on the skeletal and dentolaveolar changes in Class II Division 1 malocclusion. Medicina (Kaunas). 41(5), 392-400.

5. Khoja A., Fida M. and Shaikh A. (2016), Cephalometric evaluation of the effects of the Twin Block appliance in subjects with Class II, Division 1 malocclusion amongst different cervical vertebral maturation stages. Dental press journal of orthodontics. 2173-84

6. Moyers R.E., Riolo M.L., Guire K.E., et al. (1980), Differential diagnosis of Class II malocclusions: Part 1. Facial types associated with Class II malocclusions. American journal of orthodontics. 78(5), 477-494.

\section{MẤT PROTEIN QUA RUỘT - MộT BIẾN CHỨNG NẶNG CỦA NHIỄM GIUN MÓC: BÁO CÁO CA BÊNNH}

\section{TÓM TẮT}

Mục tiêu: Mô tả đặc điểm lâm sàng, cận lâm sàng và kết quả điều trị trường hợp nhiễm giun móc có biến chứng giảm protein máu nặng. Đối tượng và phương pháp: Báo cáo ca bệnh có biến chứng nặng của giun móc tai khoa Cấp cứu và Chống đôc, Bểnh viện Nhi Trung ương. Kết quả: Trẻ gái 20 tháng tuổi, dẩn tộc Mường nhấp viên vì li bì và tiêu chảy. Xét nghiệm cho thấy trẻ thiếu máu rất nặng, bạch câuu ưa acid tăng cao và protein máu giảm nặng. Bệnh nhân được điều trị tình trạng cấp cứu và xác định những căn nguyên gây giảm protein máu; loai trừ bênh lý: sựy dinh dưỡng, gan và thận,... Dựa vào yếu tố dịch tê̂ và các triêu chứng gợi ý, chúng tôi đã chỉ định xét nghiệm tìm kí sinh trùng trong đó có tìm trứng giun móc đồng thời định lượng nồng độ alpha 1 antitrypsin (A1AT) trong phân. Kết quả mẫu phân có rất nhiều trứng giun móc $(+++)$ và tăng nồng độ $A 1 A T(106,2$ $\mathrm{mg} / \mathrm{dL}$ ). Chẩn đoán xác định là mất protein qua ruột (PLE) do nhiễm giun móc. Điều trị bằng albendazol trong 3 ngày. Sau 16 ngày chẩn đoán và điêu trị, bệnh nhân đại tiện bình thường, hết phù, protein máu không giảm lại và được xuất viện. Kết luận: Mặc dù nhiễm giun móc là bệnh tương đối phổ biến ở các nước đang phát triển nhưng biến chứng năng như mất protein qua ruột thường hiếm gặp vì vậy cần được chẩn đoán và điều trị kịp thời để tránh tình trạng nguy kịch đến tính mạng.

Tư khóa: Giun móc, mất protein qua ruột, trẻ em

\section{SUMMARY}

PROTEIN - LOSING ENTEROPATHY - A SEVERE COMPLICATION OF HOOKWORM INFECTION: A CASE REPORT

Objectives: Describe clinical, investigations and treatment results of hookworm infections with severe hypoproteinemia. Subjects and methods: Report a

\footnotetext{
*Bệnh viện Nhi Trung ương

Chiu trách nhiệm chính: Lê Ngọc Duy

Email: Drduy2411@gmail.com

Ngày nhận bài: 13.9.2021

Ngày phản biện khoa học: 11.11.2021

Ngày duyệt bài: 18.11.2021
}

\section{Lê Ngọc Duy*, Trần Duy Mạnh*, Lương Thị Liên*, Đặng Thúy Hà*}

case of severe complications of hookworm at the Department of Emergency and Poison Control, National Children's Hospital. Results: A 20-month-old girl from the Muong ethnic was admitted because of lethargy and diarrhea. Initial tests showed that the child had severe anemia, with elevated eosinophils and severe hypoproteinemia. The patient was treated for the emergency condition and investigated common causes of hypoproteinemia. Patients were excluded: malnutrition, liver and kidney diseases,... Based on epidemiological factors and symptoms, we prescribed tests for parasites including worm eggs and quantified alpha 1 antitrypsin (A1AT) level in the stool. The child's stool showed a lot of hookworm eggs $(+++)$ and increased A1AT concentration (106.2 mg/dL). The patient was confirmed with protein-losing enteropathy (PLE) due to hookworm infection and was treated with albendazole for 3 days. After 16 days of diagnosis and treatment, the patient had normal bowel movements, no edema, no reduction in serum protein and was discharged. Conclusion: Although hookworm infection is a common disease in developing countries, severe complications of hookworm such as proteinlosing enteropathy are rare, so prompt diagnosis and treatment is required to avoid life-threatening.

Keywords: Hookworm, protein-losing enteropathy, child

\section{I. ĐĂT VẤN ĐỀ}

Giun móc là một trong những bệnh giun lây truyền qua đất, khá phổ biến ở các nước có khí hậu nhiệt đới và cận nhiệt đới. Theo Tổ chức Y tể thế giới ước tính trên thế giới có 1,5 tỷ người nhiễm giun móc/mỏ. Ở Việt Nam, bệnh giun móc đứng hàng thứ hai sau bệnh giun đũa, qua các kết quả điêu tra, tỉ lệ nhiễm giun móc ở Việt Nam từ $3-80 \%$ tùy theo tính chất nghề nghiệp, tập quán canh tác, điều kiên vê sinh và tính chất thổ nhưỡng ở từng vùng. Ở miền Bắc tỉ lệ nhiễm ở đồng bằng từ 30 - 60\%, vùng trung du 64\% và vùng núi $61 \%$ [1].

Vòng đời của giun móc từ giai đoạn trứng trong phân được bài xuất ra ngoài, gặp điêuu kiện thuận lợi nở thành âu trùng trong 1-2 ngày, khi 